\title{
Arginine improves nutritional quality of sow milk and piglet performance
}

\section{Rennan Herculano Rufino Moreira ${ }^{1}$ (D), Eloiza Lanferdini ${ }^{2}$, Leonardo da Silva Fonseca ${ }^{3}$ (D), Rhuan Filipe Chaves ${ }^{1}$, Cesar Augusto Pospissil Garbossa ${ }^{4}$ (iD, Alysson Saraiva ${ }^{5}$, Eduardo Terra Nogueira $^{6}$, Márvio Lobão Teixeira de Abreu ${ }^{1^{*}}$ (iD}

\author{
${ }^{1}$ Universidade Federal de Lavras, Departamento de Zootecnia, Lavras, MG, Brasil. \\ ${ }^{2}$ JBS Foods, Itajaí, SC, Brasil. \\ ${ }^{3}$ Universidade Federal dos Vales do Jequitinhonha e Mucuri, Diamantina, MG, Brasil. \\ ${ }^{4}$ Universidade de São Paulo, Pirassununga, SP, Brasil. \\ ${ }^{5}$ Universidade Federal de Viçosa, Departamento de Zootecnia, Viçosa, MG, Brasil. \\ ${ }^{6}$ Ajinomoto, São Paulo, SP, Brasil.
}

\begin{abstract}
The objective of this study was to evaluate the effect of L-arginine supplementation in lactation diets on the productive and reproductive performance of pluriparous sows and their litters. Seventy-six sows of the same genetic line were assigned to four treatments in a completely randomized design with 19 replicates. The experimental unit was the sow and its respective litter. Treatments comprised a control diet (no L-arginine supplementation) and other three diets obtained by top dressing the control diet with $0.5,1.0$, and $1.5 \%$ of L-arginine. L-arginine supplementation had no effect on any performance variables, body condition, milk production, or weaning-estrus interval. There was a quadratic effect on percentage of protein and fat in milk as well as on the daily production of these components. Protein and fat percentage declined during lactation. Adding L-arginine to the diet had a quadratic effect on piglet weight at 13 and 21 days, the optimal level of L-arginine supplementation being estimated as $0.64 \%$ and $0.71 \%$, respectively. L-arginine supplementation had a quadratic effect on the weight gain of piglets during the first 13 days and on total period of lactation, the optimal level of L-arginine supplementation being estimated as $0.60 \%$ and $0.70 \%$, respectively. Supplementing lactation diets with $0.70 \%$ of L-arginine, corresponding to $45 \mathrm{~g}^{-1}$ day $^{-1}$, improves the weight gain of piglets by improving the nutritional quality of sow milk.
\end{abstract}

Key Words: amino acid, lactation, milk composition, reproduction, swine

\section{Introduction}

Genetic improvement has allowed a greater number of piglets to be born alive per litter; however, it has generated many negative aspects for lactating sows including body weight loss, increased weaning-estrus interval, and fewer piglets born in the subsequent farrowing (Boyd et al., 2000). Thus, it is necessary to determine the nutritional requirements of sows in lactation, as frequent changes in genetic lines result in increased productivity of sows (Paiva et al., 2006).

Various options have been tested to overcome the challenges mentioned above, such as adjustments of amino acid levels in the diet, which, in addition to being

Received: October 27, 2017

Accepted: January 3, 2018

*Corresponding author: marvioabreu@gmail.com

Copyright (C) 2018 Sociedade Brasileira de Zootecnia. This is an Open Access article distributed under the terms of the Creative Commons Attribution License (http://creativecommons.org/licenses/by/4.0/), which permits unrestricted use, distribution, and reproduction in any medium, provided the original work is properly cited. required for maintenance, milk production, and mammary gland growth, participate in important metabolic pathways. Among these so-called functional amino acids, arginine is particularly important because, besides being a precursor for protein synthesis, it is also a precursor for the synthesis of urea, citrulline, creatine, polyamines, ornithine, proline, agmatine, and nitric oxide (Wu et al., 2004). Nitric oxide contributes to the formation and branching of blood vessels (Matsunaga et al., 2002). Furthermore, arginine stimulates the secretion of prolactin and growth hormone and is required for mammary gland development (Zhu et al., 2017), which may affect the milk production capacity of the sow. Thus, the objective of this study was to evaluate the effect of L-arginine supplementation in lactation diets on the productive and reproductive performance of pluriparous sows and their litters.

\section{Material and Methods}

The local bioethics committee approved this study (case no. 43/13). The experiment was conducted with 76 lactating sows 
(parity 2 to 6) on a commercial pig farm located in Oliveira, Minas Gerais, Brazil (latitude: 2050'50.7444"S, longitude: $44^{\circ} 48^{\prime} 51.7428^{\prime \prime} \mathrm{W}$, and $973 \mathrm{~m}$ above sea level). Sows were selected based on their reproductive history of 12-13 piglets/ farrowing and insemination records using the same boars.

Sows were assigned to four treatments in a completely randomized design with 19 replicates. Treatments comprised a control diet (no L-arginine supplementation) and other three diets obtained by top dressing the control diet with $0.5,1.0$, and $1.5 \%$ of L-arginine with $98.5 \%$ purity. The sow and its litter represented the experimental unit. The criteria for assigning sows to treatments were based on sows with similar weights and parity order in each treatment. The lactation diet (Table 1) was the diet used on the farm but with L-arginine supplementation, and with $7 \mathrm{~kg}$ of feed being offered each day.

Samples of diet were analyzed for crude protein using the Kjeldahl method (AOAC, 2000) and for amino acids by high performance liquid chromatography (Table 2). Sows and piglets had free access to water, and piglets received no feed during the experimental period. Independently of treatments, all newborn piglets were assisted to ensure colostrum intake, and litter size was standardized to 12-13 piglets/sow by cross-fostering $48 \mathrm{~h}$ post farrowing.

Each farrowing crate had a creep area for piglets equipped with heat lamps. Sows and their piglets were

Table 1 - Ingredient composition of lactation diet

\begin{tabular}{|c|c|}
\hline Ingredient & Amount ( $\mathrm{g} \mathrm{kg}^{-1}$ as feed) \\
\hline Corn & 550.60 \\
\hline Soybean meal & 318.68 \\
\hline Soybean oil & 42.46 \\
\hline Sugar & 39.96 \\
\hline Dicalcium phosphate & 15.48 \\
\hline Limestone & 10.64 \\
\hline Salt & 5.00 \\
\hline Sodium bicarbonate & 3.00 \\
\hline Kaolin & 3.00 \\
\hline Choline chloride $60 \%$ & 0.70 \\
\hline L-lisyne 78.8 & 1.50 \\
\hline L-threonine 99 & 0.74 \\
\hline DL-methionine 99 & 0.79 \\
\hline Mineral premix ${ }^{1}$ & 1.00 \\
\hline Vitamin premix ${ }^{2}$ & 0.40 \\
\hline Citric acid & 2.00 \\
\hline Nutritional supplement $^{3}$ & 4.05 \\
\hline
\end{tabular}

${ }^{1}$ The mineral premix provided the following quantities of minerals per kilogram of complete diet: $45 \mathrm{mg} \mathrm{kg}^{-1}$ copper; $275 \mathrm{mg} \mathrm{kg}^{-1}$ iron; $8.5 \mathrm{mg} \mathrm{kg} \mathrm{mg}^{-1}$ phosphorus; $85 \mathrm{mg} \mathrm{kg}{ }^{-1}$ fluorine; $1.75 \mathrm{mg} \mathrm{kg}^{-1}$ iodine; $125 \mathrm{mg} \mathrm{kg}^{-1}$ manganese; $0.75 \mathrm{mg} \mathrm{kg}^{-1}$ selenium; $4.9 \mathrm{mg} \mathrm{kg}^{-1}$ sodium; $275 \mathrm{mg} \mathrm{kg}{ }^{-1}$ zinc; $0.5 \mathrm{mg} \mathrm{kg}^{-1}$ chrome; $100 \mathrm{mg} \mathrm{kg}^{-1}$ zinc bacitracin.

${ }^{2}$ The vitamin premix provided the following quantities of vitamins per kilogram of complete diet: $9000 \mathrm{IU} \mathrm{kg} \mathrm{kg}^{-1}$ retinol; $1500 \mathrm{IU} \mathrm{kg} \mathrm{kg}^{-1}$ cholecalciferol; $60 \mathrm{mg} \mathrm{kg} \mathrm{g}^{-1}$ dl- $\alpha$-tocopherylacetate; $3 \mathrm{mg} \mathrm{kg}^{-1}$ vitamin $\mathrm{K} ; 25 \mathrm{mg} \mathrm{kg}^{-1}$ vitamin $\mathrm{B} 12 ; 40 \mathrm{mg} \mathrm{kg}^{-1}$ niacin; $20 \mathrm{mg} \mathrm{kg} \mathrm{mg}^{-1}$ pantothenic acid; $2.6 \mathrm{mg} \mathrm{kg}^{-1}$ folic acid; $0.27 \mathrm{mg} \mathrm{kg}^{-1}$ biotin; $336 \mathrm{mg} \mathrm{kg}{ }^{-1}$ choline; $4 \mathrm{mg} \mathrm{kg}-1$ pyridoxine; $6 \mathrm{mg} \mathrm{kg}{ }^{-1}$ riboflavin; $1.3 \mathrm{mg} \mathrm{kg}$ thiamine.

${ }^{3}$ Nutritionnal supplement: inactivating mycotoxins and antioxidant. weighed individually on the $2 \mathrm{nd}, 13 \mathrm{th}$, and 21 st day of lactation to calculate the weight loss of sows as well as the body weight and weight gain of the piglets. On the 2 nd and 21 st day of lactation, the backfat and loin depth of sows were measured by ultrasound (ALOKA SSD-500) using a linear transducer of $3.5 \mathrm{MHz}$ (model UST 5011) at two positions ( $\mathrm{P} 1$ and $\mathrm{P} 2)$. The first measurement was performed at $6.5 \mathrm{~cm}$ from the dorsolumbar and $6.5 \mathrm{~cm}$ from the last rib in the caudal direction (P1); the second measurement was performed at $6.5 \mathrm{~cm}$ from the dorsolumbar and $6.5 \mathrm{~cm}$ from the last rib in the cranial direction (P2). A local trichotomy was performed to improve the visualization of the points.

On the 2nd, 13th, and 21st day of lactation, piglets were separated from sows for $1 \mathrm{~h}$, after which $1 \mathrm{~mL}$ of oxytocin was injected into the ear vein of 13 sows per treatment with similar body condition. A total of $80 \mathrm{~mL}$ of milk per sow was collected by manual extraction from the first eight mammary glands, four from each side, then labeled and stored at $-20^{\circ} \mathrm{C}$ for later analysis of fat and protein content.

Six replicates per treatment were used to evaluate the percentage of fat, using methodologies described in Instruction no. 68 of 12/12/2006, which provides physical and chemical analytical methods for the official control of milk and dairy products (Brasil, 2006). For crude protein analysis,

Table 2 - Analyzed amino acids and nutritional composition of basal diet

\begin{tabular}{lc}
\hline Amino acid & Basal diet $\left(\mathrm{g} \mathrm{kg}^{-1}\right.$ as fed $)$ \\
\hline Lysine & 10.79 \\
Threonine & 8.32 \\
Methionine & 2.68 \\
Cystine & 2.73 \\
Methionine + cystine & 5.41 \\
Alanine & 8.97 \\
Arginine & 11.13 \\
Aspartic acid & 17.28 \\
Glutamic acid & 30.70 \\
Glycine & 7.28 \\
Histidine & 6.29 \\
Isoleucine & 7.26 \\
Leucine & 16.05 \\
Phenylalanine & 9.23 \\
Serine & 8.76 \\
Tyrosine & 6.79 \\
Valine & 8.10 \\
Tryptophan & 1.89 \\
Crude protein $\left(\mathrm{g} \mathrm{kg}^{-1}\right)$ & 173.40 \\
Dry matter $\left(\mathrm{g} \mathrm{kg}^{-1}\right)$ & 896.50 \\
Calculated value & \\
Metabolizable energy $\left(\mathrm{kcal}^{-1} \mathrm{~kg}^{-1}\right)$ & 3445.90 \\
Sodium & 2.16 \\
Calcium & 8.81 \\
Available phosphorus & 3.90 \\
Crude fiber & 26.30 \\
\hline
\end{tabular}


seven replicates per treatment were evaluated; the $\mathrm{N}$ in milk was analyzed using the Kjeldahl method (AOAC, 2000).

The milk yield of sows was estimated using the equation: Milk yield $\left(\mathrm{g} \mathrm{day}^{-1}\right)=(0.718 \times$ piglet daily weight $(\mathrm{g})-4.9)$ $\times$ number of piglets

\subsection{9}

(Noblet and Etianne, 1989). Based on daily milk yield and the concentration of protein and fat in the milk, daily fat and protein production were estimated.

After weaning, all sows received the same management for detection of return to estrus, which consisted of daily use of boar contact at $9.00 \mathrm{~h}$. The day after weaning, on which sows were inseminated, was recorded to evaluate the weaningestrus interval (WEI). Farrowing room temperature and relative humidity during the lactation period were recorded every $10 \mathrm{~min}$ by a data logger (model HT-500) placed in the middle of the room at half the height of the body of sows.

The analysis of variance was performed according to the statistical model below:

$$
Y i j=\mu+G i+\varepsilon i j,
$$

in which $Y i j=$ observation of the effect of L-arginine level $i$ and at replication $j, \mu=$ overall mean, $G i=$ effect of L-arginine inclusion levels, and $\varepsilon i j=$ random error associated with each observation.
Data were analyzed using SAS (Statistical Analysis System, version 9.0) and subjected to the Shapiro-Wilk test $(\alpha=0.05)$ to ensure normality. Data with normal distribution were subjected to regression analysis to determine the optimum level of L-arginine supplementation. The Tukey test $(\alpha=0.05)$ was performed to compare the mean days of lactation. Data that were not normally distributed were normalized, when possible, using the PROC RANK procedure of SAS, and non-normalized data were compared using the Kruskal-Wallis test $(\alpha=0.05)$.

\section{Results}

L-arginine supplementation during lactation did not affect $(\mathrm{P}>0.05)$ average daily feed intake (ADFI), body condition, or the weaning-estrus interval of sows (Table 3 ). There was no change $(\mathrm{P}>0.05)$ in the WEI, which was an average of 4.08 days.

L-arginine supplementation during lactation did not affect milk yield ( $\mathrm{P}>0.05)$ (Table 4$)$, which is directly related to ADFI and body condition. Moreover, treatments had a quadratic effect $(\mathrm{P}<0.05)$ on the percentage of protein and fat in milk, estimated using the following equations, respectively: Milk protein $\left(\mathrm{g} \mathrm{kg}^{-1}\right)=56.20+5.76 \mathrm{x}-4.21 \mathrm{x}^{2}\left(\mathrm{R}^{2}=0.95\right)$

Milk fat $\left(\mathrm{g} \mathrm{kg}^{-1}\right)=69.90+6.49 \mathrm{x}-5.30 \mathrm{x}^{2}\left(\mathrm{R}^{2}=0.98\right)$

Table 3 - Performance and body condition of sows fed diets with L-arginine supplementation

\begin{tabular}{|c|c|c|c|c|c|c|}
\hline \multirow{2}{*}{ Variable } & \multicolumn{4}{|c|}{ L-arginine supplementation (\%) } & \multirow{2}{*}{ P-value } & \multirow{2}{*}{ SEM } \\
\hline & 0.0 & 0.5 & 1.0 & 1.5 & & \\
\hline Daily feed intake (g) & 6,415 & 6,398 & 6,409 & 6,597 & 0.714 & 434.36 \\
\hline \multicolumn{7}{|l|}{ Sow weight $(\mathrm{kg})$} \\
\hline 2nd day & 254.89 & 254.79 & 255.21 & 255.10 & 0.999 & 18.13 \\
\hline 13th day & 249.32 & 247.42 & 249.74 & 254.47 & 0.647 & 17.41 \\
\hline 21 st day & 241.10 & 238.32 & 238.18 & 240.95 & 0.929 & 17.68 \\
\hline 2 to 21 days & 7.26 & 10.51 & 8.24 & 6.48 & 0.553 & 8.22 \\
\hline \multicolumn{7}{|l|}{ Sow weight loss $\left(\mathrm{g} \mathrm{kg}^{-1}\right)$} \\
\hline 2 to 13 days & 21.1 & 28.5 & 20.7 & 17.0 & 0.072 & 3.29 \\
\hline 2 to 21 days & 30.4 & 47.8 & 36.7 & 29.2 & 0.513 & 3.67 \\
\hline \multicolumn{7}{|l|}{ Loin depth at 2nd day $(\mathrm{cm})$} \\
\hline $\mathrm{P} 2$ & 4.40 & 4.47 & 4.36 & 4.34 & 0.905 & 0.59 \\
\hline \multicolumn{7}{|l|}{ Backfat depth at 2 nd day $(\mathrm{cm})$} \\
\hline P1 & 1.28 & 1.28 & 1.42 & 1.39 & 0.449 & 0.30 \\
\hline $\mathrm{P} 2$ & 1.20 & 1.18 & 1.27 & 1.29 & 0.741 & 0.27 \\
\hline \multicolumn{7}{|l|}{ Backfat depth at 21 st day $(\mathrm{cm})$} \\
\hline P1 & 1.34 & 1.34 & 1.39 & 1.39 & 0.969 & 0.27 \\
\hline $\mathrm{P} 2$ & 1.24 & 1.23 & 1.27 & 1.38 & 0.760 & 0.35 \\
\hline Weaning estrus interval (days) & 3.94 & 4.22 & 4.18 & 4.00 & 0.913 & 1.01 \\
\hline
\end{tabular}

SEM - standard error of the mean. 
The treatments also had a quadratic effect $(\mathrm{P}<0.05)$ on daily production of protein and fat in the milk, estimated using the following equations respectively:

Production of milk protein $\left(\mathrm{g} \mathrm{kg}^{-1}\right)=0.54+0.16 \mathrm{x}$

$$
-0.12 \mathrm{x}^{2}\left(\mathrm{R}^{2}=0.94\right)
$$

Production of milk fat $\left(\mathrm{g} \mathrm{kg}^{-1}\right)=0.78+0.17 \mathrm{x}-0.12 \mathrm{x}^{2}$

$$
\left(\mathrm{R}^{2}=0.97\right)
$$

The highest levels of concentration and production were obtained at $0.68,0.61,0.66$, and $0.66 \%$ L-arginine supplementation, respectively.

There was an effect $(\mathrm{P}<0.05)$ of days of lactation on the percentage of protein and fat in milk (Table 4). The percentage of milk protein declined from the 2 nd to the 13th day of lactation (by $22.92 \%$ ), and from this to the $21 \mathrm{st}$ day of lactation (by 4.92\%) $(\mathrm{P}<0.05)$ (Table 4); the same pattern was observed for percentage of milk fat $(\mathrm{P}<0.05)$, with reductions of 12.16 and $3.98 \%$, respectively (Table 4 ).
L-arginine did not affect $(\mathrm{P}>0.05)$ the number of piglets at 21 days of age (Table 5). However, adding L-arginine to the diets had a quadratic effect $(\mathrm{P}<0.05)$ on piglet weight at day 13 of lactation, as estimated by the equation:

Weight of piglets at 13 days $(\mathrm{g})=3988.53+490.89 \mathrm{x}$

$$
-385.40 \mathrm{x}^{2}\left(\mathrm{R}^{2}=0.78\right)
$$

and on piglet weight at day 21 of lactation $(\mathrm{P}<0.05)$, as estimated by the equation:

Weight of piglets at 21 days $(\mathrm{g})=6287.09+917.31 \mathrm{x}$

$$
-642.20 x^{2}\left(R^{2}=0.82\right)
$$

with weights at 13 and 21 days being highest for 0.64 and $0.71 \%$ L-arginine, respectively. Similarly, L-arginine influenced $(\mathrm{P}<0.05)$ piglet weight gain during the first 13 days of lactation in a quadratic way, as estimated by the equation:

\begin{tabular}{|c|c|c|c|c|c|c|c|c|c|}
\hline \multirow{2}{*}{ Variable } & \multicolumn{4}{|c|}{ L-arginine supplementation $(\%)$} & \multirow{2}{*}{ Average } & \multirow{2}{*}{ SEM } & \multicolumn{3}{|c|}{ P-value ${ }^{1}$} \\
\hline & 0.0 & 0.5 & 1.0 & 1.5 & & & $\mathrm{~L}$ & Q & $\mathrm{C}$ \\
\hline Milk yield $\left(\mathrm{kg} \mathrm{day}^{-1}\right)$ & 11.14 & 11.65 & 11.55 & 11.16 & & 1.51 & 0.975 & 0.231 & 0.844 \\
\hline \multicolumn{10}{|l|}{ Milk protein concentration $\left(\mathrm{g} \mathrm{kg}^{-1}\right)$} \\
\hline 2nd day & 68.7 & 73.0 & 65.4 & 67.8 & $68.5 \mathrm{~A}$ & 10.4 & 0.339 & 0.296 & 0.299 \\
\hline 13th day & 51.9 & 53.2 & 57.6 & 48.9 & $52.8 \mathrm{~B}$ & 5.7 & 0.446 & 0.151 & 0.073 \\
\hline 21 st day & 48.7 & 52.1 & 51.4 & 48.5 & $50.2 \mathrm{C}$ & 6.2 & 0.850 & 0.912 & 0.775 \\
\hline Average $^{2}$ & 56.4 & 59.4 & 58.1 & 55.0 & 56.8 & 5.4 & 0.728 & 0.035 & 0.636 \\
\hline Daily protein production $\left(\mathrm{kg} \text { day }^{-1}\right)^{3}$ & 0.64 & 0.67 & 0.67 & 0.62 & 0.65 & 0.06 & 0.206 & 0.002 & 0.396 \\
\hline \multicolumn{10}{|l|}{ Milk fat concentration $\left(\mathrm{g} \mathrm{kg}^{-1}\right)$} \\
\hline 2nd day & 76.3 & 79.1 & 79.6 & 74.1 & $77.3 \mathrm{~A}$ & 4.3 & 0.565 & 0.889 & 0.559 \\
\hline 13th day & 68.1 & 69.6 & 68.0 & 65.8 & $67.9 \mathrm{~B}$ & 3.1 & 0.421 & 0.501 & 0.641 \\
\hline 21 st day & 64.9 & 67.5 & 64.9 & 63.6 & $65.2 \mathrm{C}$ & 2.7 & 0.064 & 0.092 & 0.150 \\
\hline Average $^{4}$ & 69.8 & 72.1 & 70.8 & 67.8 & 70.1 & 6.2 & 0.036 & 0.001 & 0.587 \\
\hline Daily fat production $\left(\mathrm{kg} \mathrm{day}^{-1}\right)^{5}$ & 0.78 & 0.84 & 0.82 & 0.76 & 0.80 & 0.07 & 0.469 & 0.022 & 0.693 \\
\hline
\end{tabular}

Weight gain at 13 days $\left(\mathrm{g} \mathrm{day}^{-1}\right)=222.32+34.47 \mathrm{x}$

$$
-28.64 \mathrm{x}^{2}\left(\mathrm{R}^{2}=0.85\right)
$$

Table 4 - Sow milk yield and nutritional composition according to lactation period and L-arginine supplementation in the diet

SEM - standard error of the mean.

Different letters in the column differ by Tukey test $(\mathrm{P}<0.05)$

${ }^{1} \mathrm{~L}, \mathrm{Q}$, and $\mathrm{C}=$ linear, quadratic, and cubic effects, respectively, concerning the inclusion of $\mathrm{L}$-arginine in the diet.

${ }^{2} \hat{Y}=56.20+5.76 \mathrm{x}-4.21 \mathrm{x}^{2}\left(\mathrm{R}^{2}=0.95\right)$.

\begin{tabular}{|c|c|c|c|c|c|c|c|c|}
\hline \multirow{3}{*}{ Variable } & \multicolumn{4}{|c|}{ L-arginine supplementation (\%) } & \multirow{3}{*}{ SEM } & \multirow{2}{*}{\multicolumn{3}{|c|}{ P-value ${ }^{1}$}} \\
\hline & 0.0 & 0.5 & 1.0 & 1.5 & & & & \\
\hline & $\mathrm{n}=16$ & $\mathrm{n}=15$ & $\mathrm{n}=16$ & $\mathrm{n}=14$ & & $\mathrm{~L}$ & Q & $\mathrm{C}$ \\
\hline Piglets/sow at 2nd day & 13.12 & 12.87 & 12.94 & 13.14 & 0.88 & 0.944 & 0.318 & 0.850 \\
\hline Piglets/sow at 21 st day & 12.75 & 12.53 & 12.81 & 12.71 & 1.13 & 0.900 & 0.846 & 0.509 \\
\hline Weight at 2nd day (g) & 1540 & 1600 & 1560 & 1560 & 170 & 0.846 & 0.430 & 0.435 \\
\hline Weight at 13 th day $(\mathrm{g})^{2}$ & 3988 & 4137 & 4094 & 3858 & 382 & 0.367 & 0.048 & 0.246 \\
\hline Weight at 21 st day $(g)^{3}$ & 6287 & 6585 & 6562 & 6218 & 522 & 0.791 & 0.016 & 0.248 \\
\hline ADG from $2-13$ days $(\mathrm{g})^{4}$ & 222.3 & 232.4 & 228.2 & 209.6 & 27.3 & 0.205 & 0.039 & 0.306 \\
\hline ADG from 2-21 days $(\mathrm{g})^{5}$ & 249.7 & 263.4 & 262.0 & 245.6 & 24.8 & 0.714 & 0.017 & 0.326 \\
\hline
\end{tabular}

${ }^{3} \hat{Y}=0.54+0.16 x-0.12 x^{2}\left(R^{2}=0.94\right)$

${ }^{4} \hat{Y}=69.90+6.49 x-5.30 x^{2}\left(R^{2}=0.97\right)$

${ }^{5} \hat{Y}=0.78+0.17 x-0.12 x^{2}\left(R^{2}=0.97\right)$

Table 5 - Live weight and average daily gain of piglets from lactating sows fed diet with L-arginine supplementation

SEM - standard error of the mean.

${ }^{1} \mathrm{~L}, \mathrm{Q}$, and $\mathrm{C}=$ linear, quadratic, and cubic effects, respectively, concerning the inclusion of $\mathrm{L}$-arginine in the diet.

${ }^{2} \hat{\mathrm{Y}}=3988.53+490.89 \mathrm{x}-385.40 \mathrm{x}^{2}\left(\mathrm{R}^{2}=0.78\right)$

${ }^{3} \hat{\mathrm{Y}}=6287.09+917.31 \mathrm{x}-642.20 \mathrm{x}^{2}\left(\mathrm{R}^{2}=0.82\right)$

${ }^{4} \hat{Y}=222.32+34.47 \mathrm{x}-28.64 \mathrm{x}^{2}\left(\mathrm{R}^{2}=0.85\right)$.

${ }^{5} \hat{\mathrm{Y}}=249.69+42.40 \mathrm{x}-30.09 \mathrm{x}^{2}\left(\mathrm{R}^{2}=0.86\right)$. 
and over the total period $(\mathrm{P}<0.05)$, as estimated by the equation:

Weight gain at 21 days $\left(\mathrm{g} \mathrm{day}^{-1}\right)=249.69+42.40 \mathrm{x}$

$$
-30.09 \mathrm{x}^{2}\left(\mathrm{R}^{2}=0.86\right)
$$

(Table 5), with weight gains being highest for 0.60 and $0.70 \% \mathrm{~L}$-arginine, respectively.

\section{Discussion}

The temperature at which the sows were housed was close to that suggested by Nääs (2000), ranging from 12 to $25^{\circ} \mathrm{C}$; the relative humidity was consistent with Veit and Troutt (1982), ranging from 55 to $75 \%$ (Figure 1). Thus, it can be inferred that animals were in their thermal comfort zone for most of the time.

The ADFI of sows was $6,455 \mathrm{~g} \mathrm{day}^{-1}$. As the daily supply of feed was fixed at $7 \mathrm{~kg} \mathrm{day}^{-1}$, it can be inferred that sows were able to reach their physiological limit of intake. According to Mello (1993), an imbalance of amino acids in the diet reduces voluntary feed intake; however, sows are unaffected if the digestible arginine:lysine ratio is less than 3:1 (Wu et al., 2013). In this study, the maximum ratio between these two amino acids was 2.89 , which could explain why there was no effect of L-arginine on ADFI. The ADFI of lactating sows can be affected by diet flavor, parity, body weight, litter size, and environment (Domiciano et al., 2008; Mosnier et al., 2010; Wang et al., 2014). In this study, these factors were kept unchanged among treatments.

The weight of sows was not affected by L-arginine. According to Schenkel et al. (2010), sows lose weight during lactation, and the magnitude of this loss is important for their future reproductive performance. It has been assumed that if weight loss is less or around $13 \%$, it does not affect the future reproductive performance of sows (Hoving et al., 2011).

In this study, sows in all treatments lost less than $5.0 \%$ of their weight at weaning, indicating minor body mobilization during lactation. This can be explained by the fact that sows were not subjected to dietary restrictions

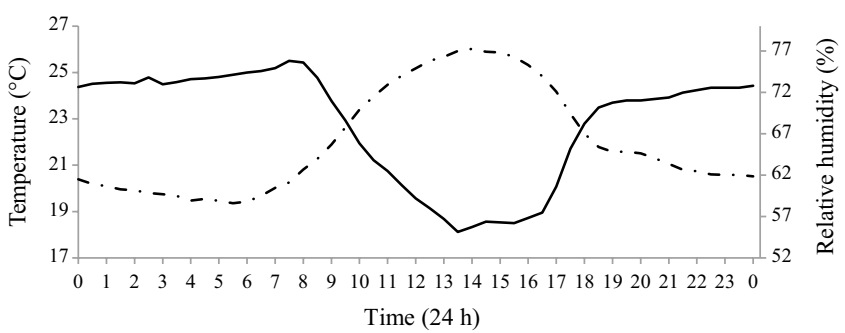

Figure 1 - Average temperature $\left({ }^{\circ} \mathrm{C}\right.$, dashed line) and average air relative humidity $(\%$, continued line) during the trial period. during the study, given that feed leftovers were observed in all treatments. Another important factor is the nutritional quality of the diet, especially in relation to lysine, which is the major limiting amino acid for lactating sows, affecting both milk yield and the extent of body mobilization (Nunes et al., 2006). In this study, the average digestible lysine intake was $61.3 \mathrm{~g} \mathrm{day}^{-1}$, meeting the requirements for this amino acid according to Rostagno and Gomes (2011).

Weaning to estrus interval was consistent with the results observed by Mateo et al. (2008), who used 1\% L-arginine, and with those obtained by Schenkel et al. (2010), who found that $90 \%$ of the sows returned to estrus between three and five days after weaning. Based on reports by Schenkel et al. (2010), sows may lose up to $10 \%$ of their body weight during lactation without affecting subsequent reproductive performance, and thus the observed WEI was considered normal and was not affected by the weight loss of the sows (average loss of $3.60 \%$ ).

Milk production is directly related to ADFI and body condition. L-arginine supplementation during lactation did not affect these variables; however, it did affect milk nutritional quality (protein and fat). Milk nutrients are derived from two sources: feed and body tissues (fat and muscle) mobilized during lactation (Lima et al., 2011). As neither ADFI nor the mobilization of tissues, as indicated by backfat thickness and loin depth, were affected by supplementation with L-arginine, it is possible that the observed improvement in milk nutritional quality was due to the metabolic roles of arginine in the mammary glands and improvements in the use efficiency of dietary protein, as arginine level in the diets was the only factor that differed between treatments.

Mammary blood flow and angiogenesis are regulated by nitric oxide, which is a product of arginine metabolism (Lacasse and Prosser, 2003). In this sense, arginine supplementation in the diet of sows may improve blood flow and enhance nutrient flow to the mammary glands, contributing to milk protein synthesis due to increased nitric oxide synthesis in the endothelial cells of blood vessels (Wu and Meininger, 2002). Furthermore, milk production is highly correlated with growth and development of mammary glands (Kim et al., 2000). Zhu et al. (2017) found that $1 \% \mathrm{~L}$-arginine increased the secretion of prolactin and growth hormone, both of which are necessary for mammary gland development. Moreover, Mateo et al. (2008) found that $1 \% \mathrm{~L}$-arginine in the diet of gilts increased the flow of amino acids to the mammary glands through the action of arginine on anabolic hormones such as insulin, which was present at higher concentrations in the plasma of gilts fed diets supplemented with this amino acid, especially during the first week of lactation. 
According to Trottier et al. (1997), $188.5 \mathrm{~g}$ of essential amino acids are absorbed by mammary glands every day, and only $49 \mathrm{~g}$ or $25 \%$ of these amino acids are retained in the mammary glands. These amino acids can be used for the synthesis of structural proteins and remodeling of mammary tissue cells, which may have influenced the increase in percentage milk protein.

Amino acids retained in the mammary glands can also serve as energy substrates. It is possible that arginine helped increase milk fat, since it has been proven that arginine increases the availability of amino acids to mammary glands. Zhu et al. (2017) supplemented the diet of gilts with $1 \% \mathrm{~L}$-arginine and found an increase in the amount of fat in the milk; this result is similar to the results of the present trial. Another important factor is the ratio of amino acids in the feed (Trottier et al., 1997), the recommended ratio of digestible arginine:digestible lysine of 1.43:1 to ensure the maximum amino acid absorption by the mammary glands (Guan et al., 2004) was achieved in this study.

Furthermore, supplementation with 1\% L-arginine stimulates insulin production, which participates in lipoprotein lipase activation (Mateo et al., 2008). The increased insulin activates lipoprotein lipase enzyme, which releases glycerol and fatty acids of triglycerides that may be absorbed into the peripheral tissues, especially muscle and fat for energy and storage or for milk fat synthesis.

The changes in milk composition on the days of evaluation were consistent with several other studies (Daza et al., 2004; Aguinaga et al., 2011; Wang et al., 2013) that observed a reduction in the nutritional quality of milk as lactation progressed.

The higher weight gain of piglets from sows fed L-arginine-supplemented diets in this study may be attributed to the improvement in the nutritional quality of milk (protein and fat), as piglets did not have access to another source of feed. Besides, milk production did not vary among treatments, and tissue mobilization among sows was similar.

According to Kim and $\mathrm{Wu}$ (2009), supplementing the diet of lactating gilts with $0.83 \% \mathrm{~L}$-arginine increased piglet growth. This amount of L-arginine was a little less than the observed level in our study; considering that gilts have higher nutritional requirements, as they are still developing and in full reproductive activity, this suggests that a higher level of L-arginine would be needed to keep increasing the weight of piglets for gilts.

\section{Conclusions}

Supplementation of $0.70 \% \mathrm{~L}$-arginine in the lactation diet, corresponding to the intake of $45 \mathrm{~g} \mathrm{day}^{-1}$ of $\mathrm{L}$-arginine, improves the weight gain of piglets during the total trial period, which may be explained by the improvement in nutritional quality of the milk of pluriparous sows.

\section{Acknowledgments}

The authors want to acknowledge the Conselho Nacional de Desenvolvimento Científico e Tecnológico $(\mathrm{CNPq})$, the Instituto Nacional de Ciência e Tecnologia de Ciência Animal (INCT-CA/CNPq), the Fundação de Amparo à Pesquisa do Estado de Minas Gerais (FAPEMIG), the Coordenação de Aperfeiçoamento de Pessoal de Nível Superior (CAPES), for the scholarship granted to the first author, and the Ajinomoto Animal Nutrition.

\section{References}

Aguinaga, M. A.; Carballar, F. G.; Nieto, R. and Aguilera, J. F. 2011. Production and composition of Iberian sow's milk and use of milk nutrients by the suckling Iberian piglet. Animal 5:1390-1397. https://doi.org/10.1017/S1751731111000474

AOAC - Association of Official Analytical Chemists. 2000. Official methods of analysis. 17th ed. Association of Official Analytical Chemists, Gaithersburg, MD.

Brasil. 2006. Ministério da Agricultura, Pecuária e Abastecimento. Secretaria de Defesa Agropecuária. Departamento de Inspeção de Produtos de Origem Animal. Instrução Normativa $\mathrm{n}^{\circ}$ 68, de 12 de dezembro de 2006. Dispõe sobre métodos analíticos oficiais físico-químicos para controle de leite e produtos lácteos. Brasília, DF.

Boyd, R. D.; Touchette, K. K.; Castro, G. C.; Johnston, M. E.; Lee, K. U. and Ham, K. 2000. Recent advances in amino acid and energy nutrition of sows. Asian-Australasian Journal of Animal Sciences 13:1638-1652.

Daza, A.; Riopérez, J. and Centeno, C. 2004. Changes in the composition of sows' milk between days 5 to 26 of lactation. Spanish Journal of Agricultural Research 2:333-336. https://doi.org/10.5424/sjar/2004023-102

Domiciano, T.; Costa, A. N.; Silva, J. H. V.; Dutra Júnior, W. M. and Brasil, L. H. 2008. Effects of partum order and stage of lactation on the performance of hybrid swine sows maintained in hot environments. Revista Caatinga 21:11-21.

Guan, X.; Bequette, B. J.; Ku, P. K.; Tempelman, R. J. and Trottier, N. L. 2004. The amino acid need for milk synthesis is defined by the maximal uptake of plasma amino acids by porcine mammary glands. The Journal of Nutrition 134:2182-2190. https://doi.org/10.1093/jn/134.9.2182

Hoving, L. L.; Soede, N. M.; van der Peet-Schwering, C. M. C.; Graat, E. A. M.; Feitsma, H. and Kemp, B. 2011. An increased feed intake during early pregnancy improves sow body weight recovery and increases litter size in young sows. Journal of Animal Science 89:3542-3550. https://doi.org/10.2527/jas.2011-3954

Kim, S. W.; Hurley, W. L.; Hant, I. K. and Easter, R. A. 2000. Growth of nursing pigs related to the characteristics of nursed mammary glands. Journal of Animal Science 78:1313-1318. https://doi.org/10.2527/2000.7851313x

Kim, S. W. and Wu, G. 2009. Regulatory role for amino acids in mammary gland growth and milk synthesis. Amino Acids 37:89-95. https://doi.org/10.1007/s00726-008-0151-5 
Lacasse, P. and Prosser, C. G. 2003. Mammary blood flow does not limit milk yield in lactating goats. Journal of Dairy Science 86:2094-2097. https://doi.org/10.3168/jds.S0022-0302(03)73798-9

Lima, A. L.; Oliveira, R. F. M.; Donzele, J. L.; Fernandes, H. C.; Campos, P. H. R. F. and Antunes, M. V. L. 2011. Floor cooling in farrowing room for lactating sows in the summer. Revista Brasileira de Zootecnia 40:804-8011. https://doi.org/10.1590/S1516-35982011000400014

Mateo, R. D.; Wu, G.; Moon, H. K.; Carroll, J. A. and Kim, S. W. 2008. Effects of dietary arginine supplementation during gestation and lactation on the performance of lactating primiparous sows and nursing piglets. Journal of Animal Science 86:827-835. https://doi.org/10.2527/jas.2007-0371

Matsunaga, T.; Weihrauch, D. W.; Moniz, M. C.; Tessmer, J.; Warltier, D. C. and Chilian, W. M. 2002. Angiostatin inhibits coronary angiogenesis during impaired production of nitric oxide. Circulation 105:2185-2191. https://doi.org/10.1161/01.CIR.0000015856.84385.E9

Mello, J. P. F. 1993. Amino acid supplementation of cereal-based diets for non-ruminants. Animal Feed Science and Technology 45:1-18. https://doi.org/10.1016/0377-8401(93)90068-U

Mosnier, E.; Etienne, M.; Ramaekers, P. and Père, M.C. 2010. The metabolic status during the peri partum period affects the voluntary feed intake and the metabolism of the lactating multiparous sow. Livestock Science 127:127-136. https://doi.org/10.1016/j.livsci.2009.06.023

Nääs, I. A. 2000. A influência do meio ambiente na reprodução das porcas. p.142-151. In: Anais do $5^{\circ}$ Seminário Internacional de Suinocultura, São Paulo, SP.

Noblet, J. and Etianne, M. 1989. Estimation of sow milk nutrient output. Journal of Animal Science 67:3352-3359. https://doi.org/10.2527/jas1989.67123352x

Nunes, C. G. V.; Oliveira, R. F. M.; Donzele, J. L.; Oliveira, W. P.; Silva, B. A. N. and Abreu, M. L. T. 2006. Lysine levels in diets for lactating sows. Revista Brasileira Zootecnia 35:1744-1751. https://doi.org/10.1590/S1516-35982006000600023

Paiva, F. P.; Donzele, J. L.; Oliveira, R. F. M.; Abreu, M. L. T.; Costa, E. P. and Apolônio, L. R. 2006. Digestible energy in the diet of primiparous lactating sows. Arquivo
Brasileiro de Medicina Veterinária e Zootecnia 58:234-241. https://doi.org/10.1590/S0102-09352006000200012

Rostagno, H. S. and Gomes, P. C. 2011. Brazilian tables for poultry and swines. 3th ed. Editora UFV, Viçosa, MG.

Schenkel, A. C.; Bernardi, M. L.; Bortolozzo, F. P. and Wentz, I. 2010. Body reserve mobilization during lactation in first parity sows and its effect on second litter size. Livestock Science 132:165-172. https://doi.org/10.1016/j.livsci.2010.06.002

Trottier, N. L.; Shipley, C. F. and Easter, R. A. 1997. Plasma amino acid uptake by the mammary gland of the lactating sow. Journal of Animal Science 75:1266-1278. https://doi.org/10.2527/1997.7551266x

Veit, H. P. and Troutt, H. F. 1982. Monitoring air quality for livestock respiratory health. Veterinary Medicine and Small Animal Clinician 77:454-464.

Wang, L. S.; Su, B. C.; Shi, Z.; Shi, B. M and Shan, A. S. 2013. Dietary supplementation with maize distillers dried grains with solubles during late gestation and lactation: effects on sow and litter performance, and on colostrum and milk composition. Animal Feed Science and Technology 179:149-153. https://doi.org/10.1016/j.anifeedsci.2012.11.002

Wang, J.; Yang, M.; Xu, S.; Lin, Y.; Che, L.; Fang, Z. and Wu, D. 2014. Comparative effects of sodium butyrate and flavors on feed intake of lactating sows and growth performance of piglets. Animal Science Journal 85:683-689. https://doi.org/10.1111/asj.12193

Wu, G.; Bazer, F. W.; Satterfield, M. C.; Li, X.; Wang, X.; Johnson, G. A.; Burghardt, R. C.; Dai, Z.; Wang, J. and Wu, Z. 2013. Impacts of arginine nutrition on embryonic and fetal development in mammals. Amino Acids 45:241-256. https://doi.org/10.1007/s00726-013-1515-z

Wu, G.; Knabe, D. A. and Kim, S. W. 2004. Arginine nutrition in neonatal pigs. Journal of Nutrition 134(10 suppl):2783-2790.

$\mathrm{Wu}, \mathrm{G}$. and Meininger, C. J. 2002. Regulation of nitric oxide synthesis by dietary factors. Annual Review of Nutrition 22:61-86. https://doi.org/10.1146/annurev.nutr.22.110901.145329

Zhu, C.; Guo, C.; Gao, K.; Wang, L.; Chen, Z.; Ma, X. and Jiang, Z. 2017. Dietary arginine supplementation in multiparous sows during lactation improves the weight gain of suckling piglets. Journal of Integrative Agriculture 16:648-655. https://doi.org/10.1016/S2095-3119(16)61426-0 